\title{
Public transport analysis in the Petroșani Basin in the context of the need for sustainable mobility
}

\author{
Sorin Mihăilescu ${ }^{1 *}$, and Gabriel Praporgescu ${ }^{1}$ \\ ${ }^{11}$ University of Petroșani, Mechanical, Industrial and Transports Engineering Department, 20 \\ Universității Street, Petroșani, România
}

\begin{abstract}
Sustainable public transport requires finding a balance between economic and social objectives, ensuring the need for mobility without damaging environmental and health factors. At the level of the Petroșani Basin, the aim is to ensure the mobility of passengers as quickly as possible from one city to another (from east to west - Petrila, Petroșani, Aninoasa, Vulcan, Lupeni, Uricani) or from one part of the city to another, as the case may be. The study of population fluctuations by hours, on working or nonworking days, per season allows the realization of a public transport that ensures the movement of people as quickly and safely as possible. The purpose of this paper is to study the way in which public transport is carried out in the Petroșani Basin, the means of transport used and the possibilities to improve this activity. In the context of sustainable mobility, the paper includes necessary aspects (transport demand, influencing factors, infrastructure) in order to conclude on the future of public transport in the Petroșani Basin.
\end{abstract}

\section{Introduction}

The mobility of goods and people is one of the essential elements of urban development, characterizing the urban space and the way it works. As the population continues to be concentrated in cities, the negative impact associated with the transport of people and goods is worsening [1].

Public passenger transport is one of the most important functions of the community, ensuring the unity and coherence of activities in the community. It can be considered an indicator of the level of development of the community, being an intrinsic part of civilization. The basic feature of public transport of people by regular services is that it takes place in an organized setting, on fixed routes, with walking charts and predetermined routes. It must be carried out at the time of application and be organized in such a way as to ensure that the transport load is taken over, with an appropriate degree of comfort and safety, the purpose of an urban public transport system being to meet the movement requirements of the inhabitants, both in residential areas and in industrial and leisure areas. The quality of a trip - which is the actual product of this transport activity - involves a multitude of factors, the safety, comfort

* Corresponding author: mihailescus@gmail.com, gpraporgescu@gmail.com 
and rhythm of the trip being essential. The organization of the operation of the general public transport system in a city or area starts from the need to ensure its unitary character and from the subordination of different modes of transport to the general interest of the community, according to the limits and possibilities offered by each in taking over passengers and using the road network or specific facilities $[2,3,4]$.

The document necessary for long-term urban development, with beneficial effects on the economic and social development of the functional area The Petroșani Basin is represented by the Sustainable Urban Mobility Plan. This document is both a requirement for attracting non-reimbursable funds for urban development, but also a necessity and a first solution for tackling traffic-related problems in an integrated and strategic way, whether we are talking about people or goods, such as and urban, inter-county and adjacent mobility issues [5].

\section{Determining factors for public transport in the Petroșani Basin}

For a good knowledge of traffic phenomena in order to optimize the development of urban transport, an analysis is made of all factors and their interdependence [6]. The factors that are taken into account for the design of public passenger transport systems are very diverse and they can be classified as follows:

- Natural factors: geographical position of the area, situation of the natural environment, natural resources, demographic factors, etc.;

- Socio-political factors: number and structure of the population, standard of living, social protection measures, etc.;

- Type of ownership of the infrastructure and superstructure of the transmission system: induces, among other things, a competitive side, generally beneficial for the transmission system;

- Technical exploitation factors: capacities, speeds, flexibility, etc.;

- Economic factors: general (characterizing the economic system as a whole) and specific to the transport system.

The Petroșani Basin (Figure 1) is located in southwestern Romania, in the Southern Carpathians, between the coordinates $45^{\circ} 17^{\prime}-45^{\circ} 22^{\prime}$ north latitude and $20^{\circ} 13^{\prime}-20^{\circ} 33^{\prime}$ east longitude. Access in the Basin is made from the south through the Jiu Gorge from Târgu Jiu or from the north on the European road E79 from Simeria, from the east from Obârșia Lotrului on the national road DN7A and in perspective from the west from Herculane on the national road DN66A. The Petroșani Basin is located on the north-south railway axis, which connects Transylvania with Oltenia, through the Jiu Gorge (Simeria-Petroşani-Târgu-JiuFiliaşi) [7]. The Petroșani Basin has a length of approximately $60 \mathrm{~km}$, between the localities of Cimpa to the east and Câmpu lui Neag to the west and has a triangular shape, oriented VS-E - E-N-E. The width decreases from $9 \mathrm{~km}$, near Petrila and Livezeni localities, to 1,5 km at Câmpul lui Neag.

The state of the economy has influenced the decline of the population. The Petroșani Basin shows a decrease of approximately 36,500 inhabitants in the last 30 years. The population totals 133,392 inhabitants on January 1, 2020 compared to 135,989 inhabitants on July 1, 2018 [8]. The demographic variation highlights the reduction by $2 \%$ of the number of inhabitants with permanent residence in the area, maintaining the decreasing trend of the last 30 years $(169,856$ inhabitants in $1992,158,678$ in 2002, 146,200 in 2011, 139,718 in 2015). The graph in figure 2 shows the forecast of the population of the Petroșani Basin until 2030. The decreasing trend is probable in the current conditions, so that the number of inhabitants of the Petroșani Basin will decrease by a compound annual average of $1.4 \%$, reaching approx. 114,000 inhabitants in 2030, which is a decrease of almost $30 \%$ compared to the peak reached in 1997 [9]. 


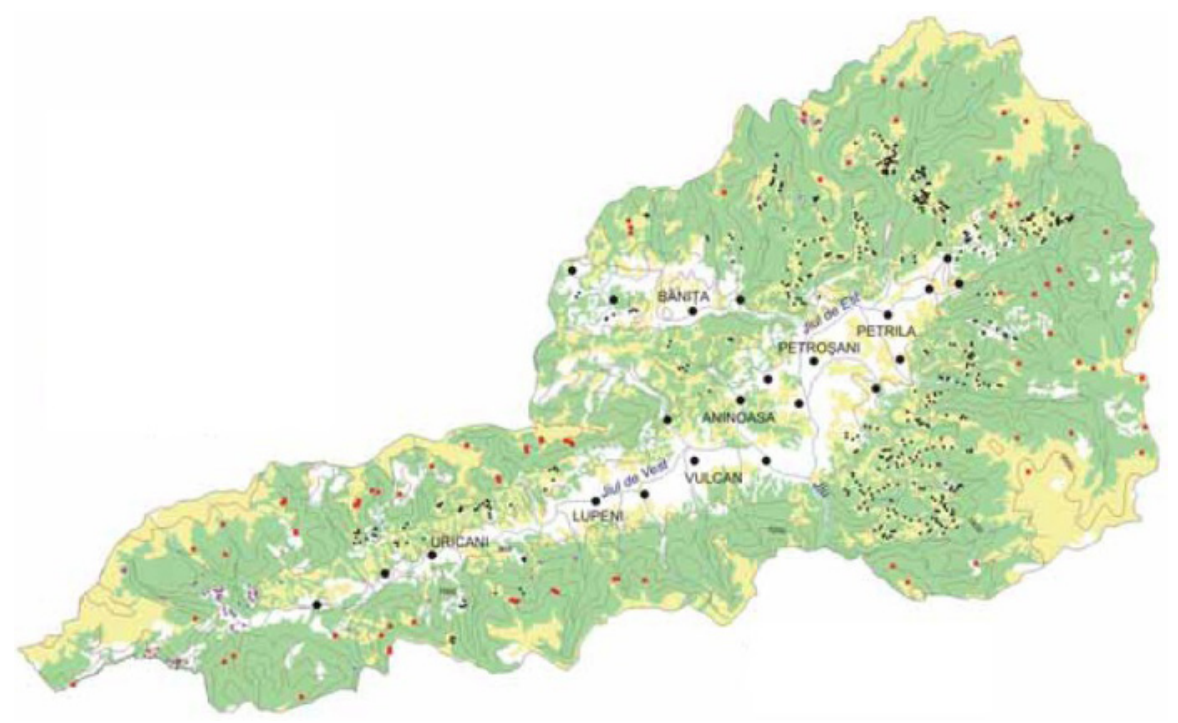

Fig. 1. Petroșani Basin.

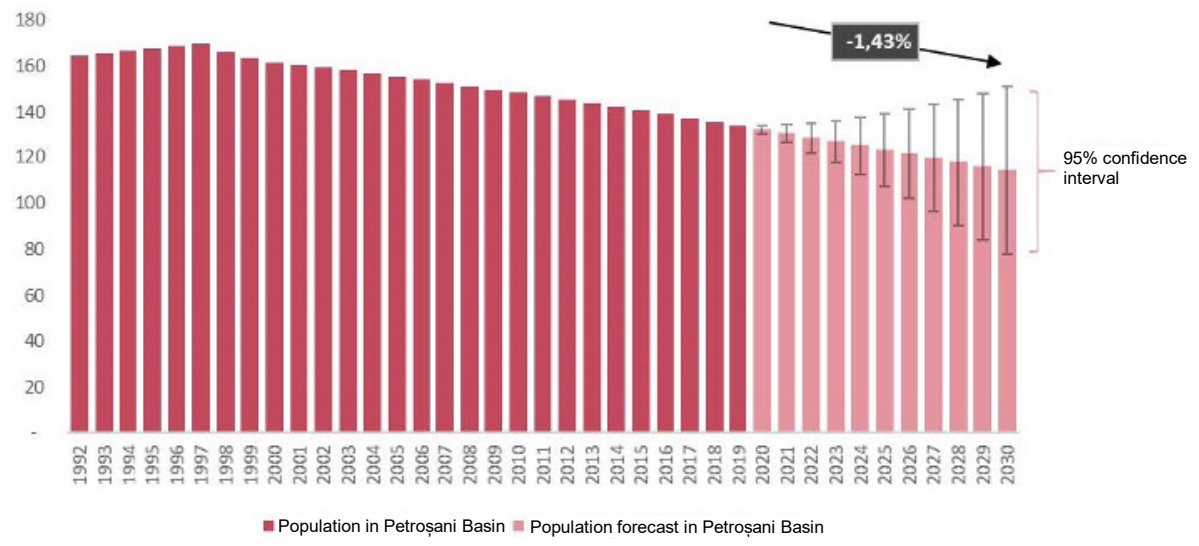

Fig. 2. Evolution and predictions regarding the population of the Petroșani Basin.

The area was based almost exclusively on employment in the extractive industry and after the closure and drastic reduction of mining activity, the development of the area ceased, living conditions deteriorated, and the reorientation to other economic sources was achieved only to a small extent. In addition to the services provided by public institutions (hospital care, education), the main employers are active in the mining industry (coal extraction), the textile industry and the automotive component industry (parts and accessories). In 2019, the Petroșani Basin registered approx. 100,000 able-bodied people, aged between 15 and 65 . Only a quarter of them are employed, compared to 1992 when over $60 \%$ of the population had a stable job (Figure 3) [9].

The geographical conditions make the only connection of the localities in the area with the municipality of Petroșani - the pole of attraction for the area - to be the national road DN $66 \mathrm{~A}$ for the cities from the west of the Basin and the county road DJ $709 \mathrm{~K}$ with the cities from the east of the Basin. Thus, between Cimpa and Câmpu lui Neag, the routes of the public transport system largely overlap, because there are no other possibilities for organizing the network. 


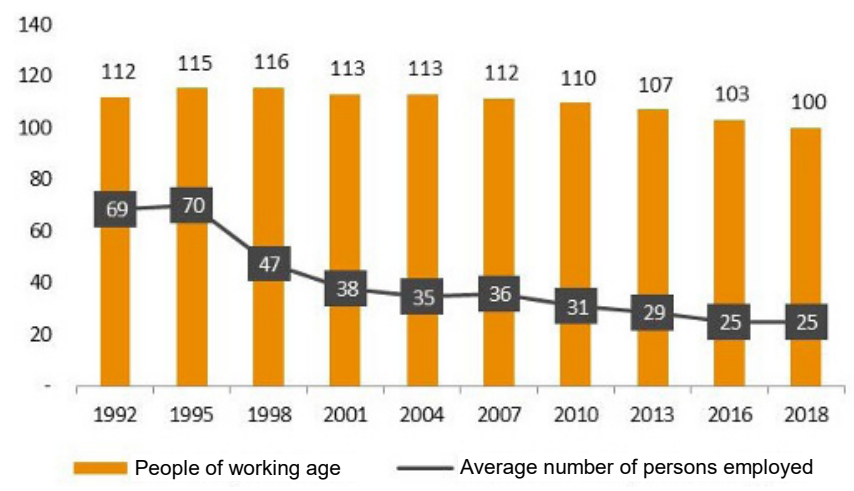

Fig. 3. The evolution of the labour force in the Petroșani Basin during 1992-2018.

Regarding the total network of roads in the Basin (Table 1), it amounts to $361 \mathrm{~km}$, distributed relatively evenly between the component localities of the micro-region, given their area [10].

Table 1. Public roads in the Petroșani Basin

\begin{tabular}{|c|c|c|c|c|}
\hline \multirow{2}{*}{$\underbrace{\text { Roads }}_{\text {City }}$} & \multirow{2}{*}{$\begin{array}{l}\text { Public roads } \\
\text { (including } \\
\text { streets), (km) }\end{array}$} & \multicolumn{2}{|c|}{ Of which ( $\mathrm{km})$ : } & \multirow{2}{*}{$\begin{array}{l}\text { Percentage of } \\
\text { modernized } \\
\text { roads }\end{array}$} \\
\hline & & Modernized & $\begin{array}{c}\text { With light asphalt } \\
\text { coatings }\end{array}$ & \\
\hline Petroșani & 120 & 67 & 0 & $55,83 \%$ \\
\hline Lupeni & 58,65 & 34,39 & 20,58 & $58,64 \%$ \\
\hline Vulcan & 31,35 & 14,6 & 3 & $46,57 \%$ \\
\hline Uricani & 44 & 22 & 0 & $50,00 \%$ \\
\hline Petrila & 65 & 33 & 32 & $50,77 \%$ \\
\hline Aninoasa & 42 & 15 & 15 & $35,71 \%$ \\
\hline Petroșani Basin & 361 & 185,99 & 70,58 & $51,52 \%$ \\
\hline
\end{tabular}

\section{Evaluation of the demand for public passenger transport}

The factors influencing the transport demand result from the following relation:

$$
Q t=f(P s, P c, V, P a, P r, D s)
$$

where: $Q t$ [passenger $\times \mathrm{km}$ or $\mathrm{t} \times \mathrm{km}$ ] - performance or volume of carriage; $P s$ - transport cost; $P c$ - the cost of related services; $V$ - related income; $P a$ - the anticipated price of displaced goods; $P r$ - consumer preferences; $D s$ - customer spatial distribution [6].

In order to evaluate the demand for public passenger transport in the Petroșani Basin, the demographic and economic situation of all localities must be taken into account. The main reasons for the trip that takes place in the Petroșani Basin are business, pleasure, the trip to and from work and in the interest of work, the trip of students to school, medical trips, 
shopping trips, leisure trips, etc. (Figure 4) [11].

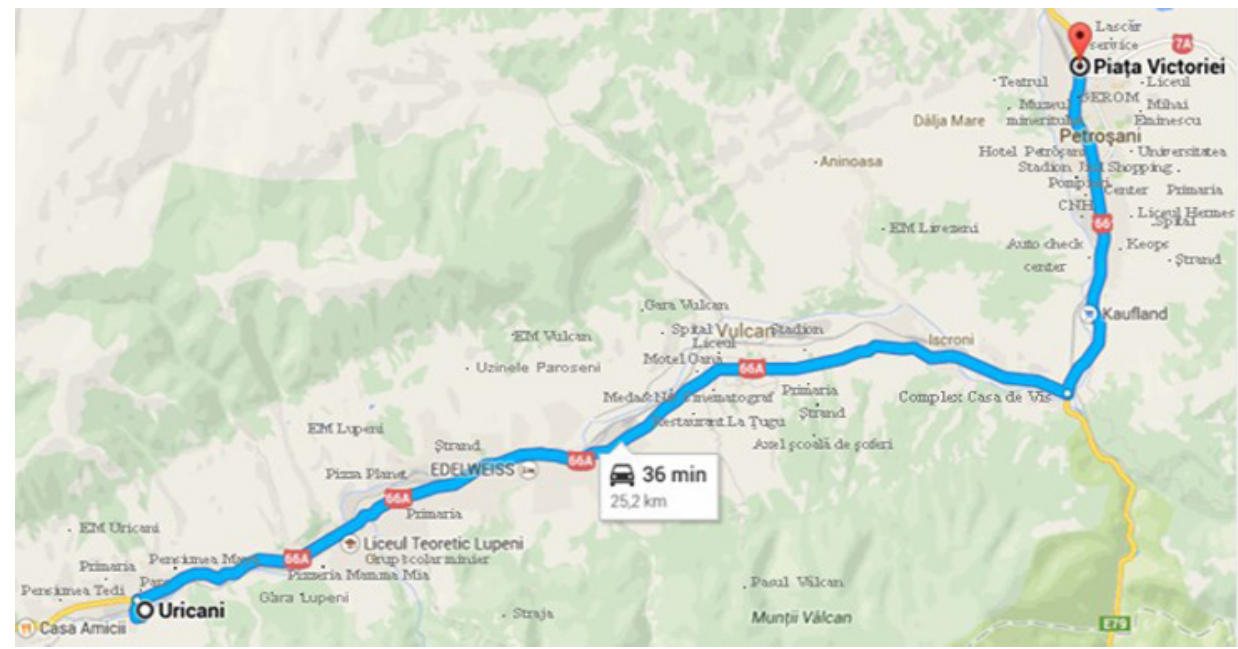

Fig. 4. Attraction points in Petroșani Basin

The connection between the localities is made by means of minibus lines operated by 2 transport operators S.C. ZMK S.R.L. (routes 1, 2, 6 and 7) and S.C. STALONE S.R.L. (routes 3, 4 and 5) (Table 2). On the 7 routes from the Petroșani Basin, minibuses with 19-22 seats are used $[9,12,13]$. At present the estimated number of passengers per day is about 4500 people. The frequency of the means of transport ensures the transport of a number of approximately 7200 people, given that each means of transport would have the maximum number of seats occupied. It should be noted that during peak hours the means of transport run at full capacity and that the transport of people by taxi was not taken into account.

In order to be able to evaluate the demand for public passenger transport on the 7 routes, we worked in two ways:

- fixed observer, in the Victoriei Square Station in Petroșani (this being the main road passenger terminal in the Petroșani Basin being positioned near the Petroșani railway station) noting the degree of loading of each means of transport leaving the station;

- mobile observer, traveling by public road transport from one end of the route to the other and noting the number of passengers going up and down at each station.

The traffic study showed the number of passengers per hour (Figure 5), the number of passengers per week (Figure 6) and the number of passengers per month (Figure 7). The results of the study are summarized in Table 2, where the number of trips per day resulted from the traffic schedule of the two public passenger transport operators $[12,13]$.

Table 2. The means of transport and the average number of passengers per journey

\begin{tabular}{|c|c|c|c|c|c|c|}
\hline No. & Route & $\begin{array}{c}\text { Means of } \\
\text { transport } \\
\text { capacity }\end{array}$ & $\begin{array}{c}\text { Number of } \\
\text { trips/day }\end{array}$ & $\begin{array}{c}\text { Average } \\
\text { number of } \\
\text { passengers/trip }\end{array}$ & $\begin{array}{c}\text { Total } \\
\text { daily } \\
\text { trips }\end{array}$ & $\begin{array}{c}\text { Annual } \\
\text { average daily } \\
\text { traffic } \\
\text { (AADT) }\end{array}$ \\
\hline 1 & Petroșani-Uricani & 22 & 82 & 15 & 1230 & 369000 \\
\hline 2 & Petroșani-Aninoasa & 22 & 15 & 11 & 165 & 49500 \\
\hline 3 & Petroșani-Lonea & 19 & 103 & 12 & 1236 & 370800 \\
\hline
\end{tabular}




\begin{tabular}{|c|c|c|c|c|c|c|}
\hline 4 & Petroșani-Cimpa & 19 & 30 & 10 & 300 & 90000 \\
\hline 5 & Petroșani-Jieț & 19 & 12 & 15 & 180 & 54000 \\
\hline 6 & $\begin{array}{c}\text { Petroșani, Piața } \\
\text { Victoriei-Str. } \\
\text { Aviatorilor }\end{array}$ & 22 & 86 & 15 & 1290 & 387000 \\
\hline 7 & $\begin{array}{c}\text { Petroșani, Str. } \\
\text { Aviatorilor-Str. } \\
\text { Popa Radu Șapcă }\end{array}$ & 22 & 2 & 9 & 18 & 5400 \\
\hline 8 & TOTAL & - & - & - & 4419 & 1325700 \\
\hline
\end{tabular}

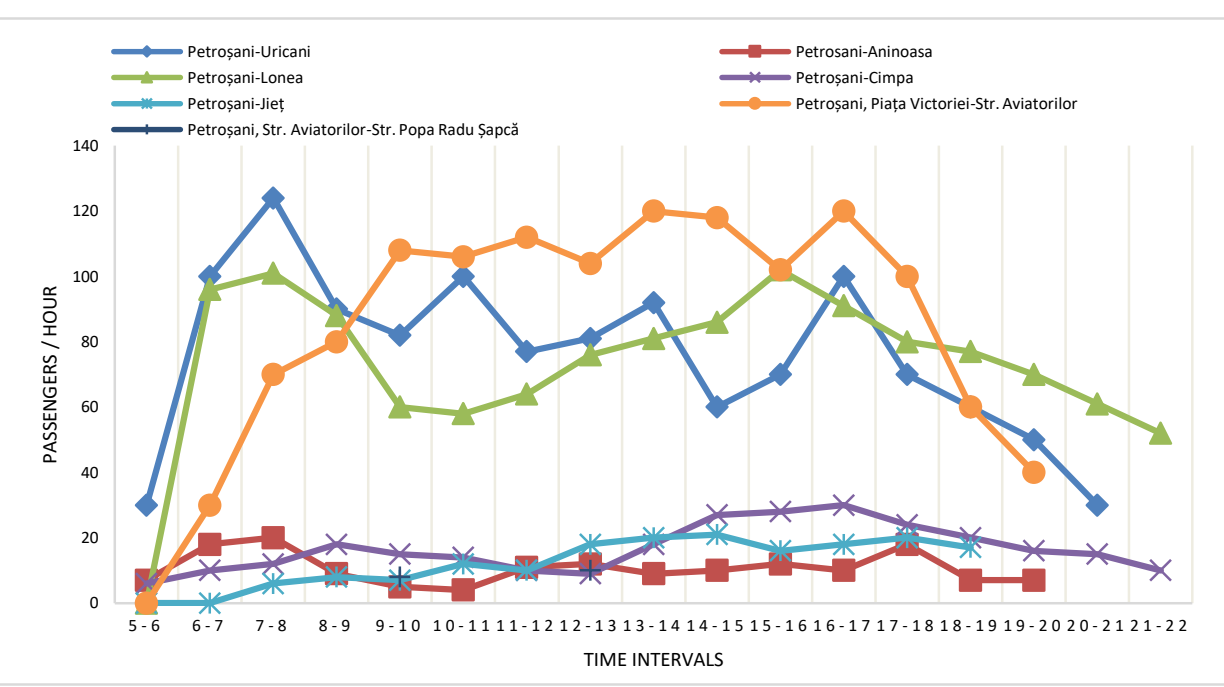

Fig. 5. Number of passengers per hour

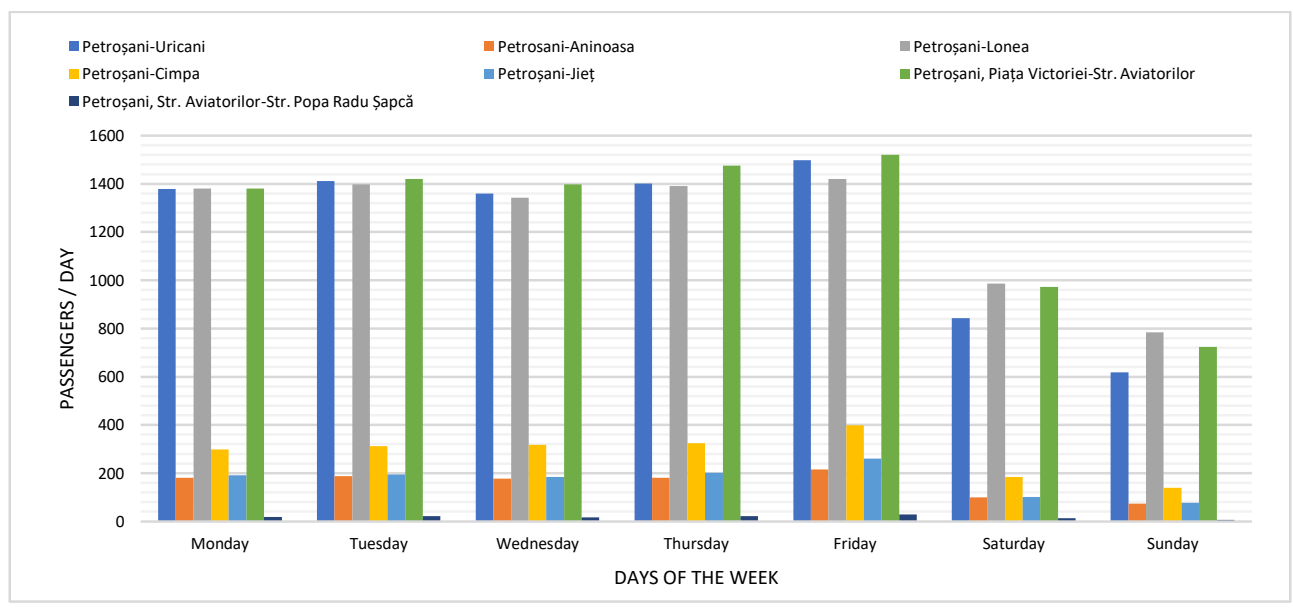

Fig. 6. Number of passengers per day

According to the estimates from the Sustainable Urban Mobility Plan and the results obtained from the traffic study, the current demand for public passenger transport services in the Petroșani Basin is about 1325700 trips per year. 


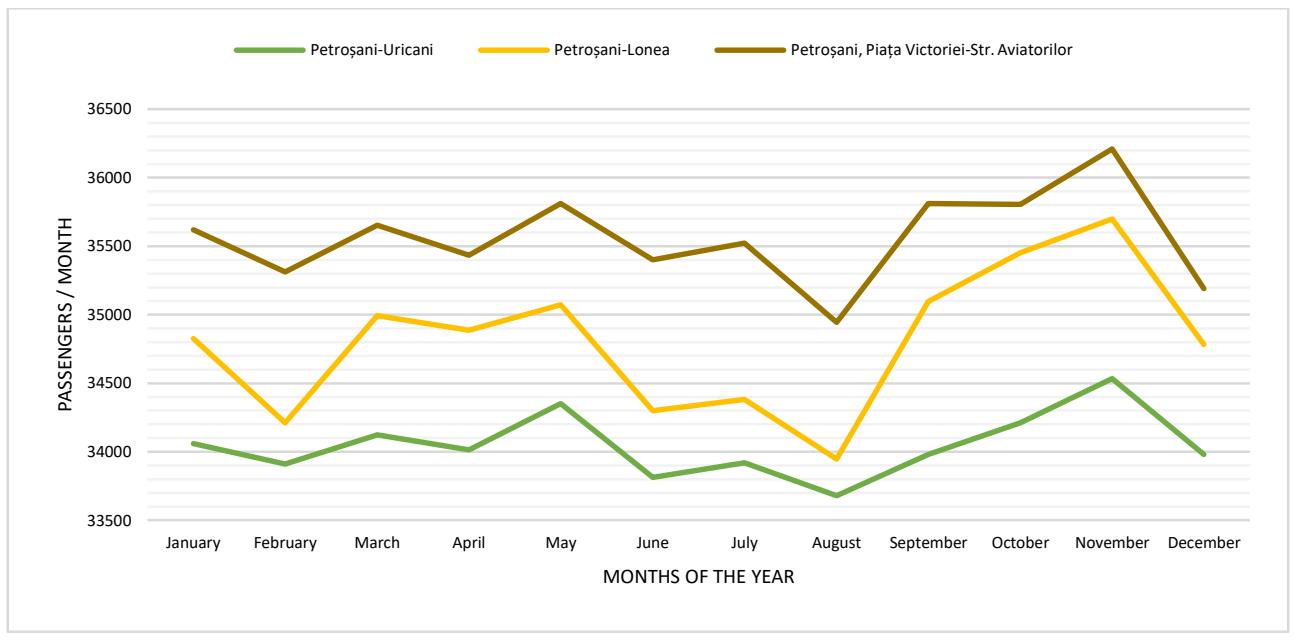

Fig. 7. Number of passengers per month for the busiest 3 routes

Taking into account the predictions regarding the demographic evolution of the population in the Petroșani Basin (figure 2), it can be estimated that the demand for public passenger transport services will decrease in the next period.

\section{SWOT ANALYSIS ON PUBLIC TRANSPORT}

A component of the analysis and evaluation of public transport in the Petroșani Basin, the SWOT analysis helped to identify and understand the strengths, weaknesses, opportunities and existing threats, which are presented in Table 3.

Table 3. SWOT analysis of public passenger transport in the Petroșani Basin

\begin{tabular}{|c|c|}
\hline STRENGTHS & WEAKNESSES \\
\hline $\begin{array}{l}\text { The continuous process of modernization of } \\
\text { the fleet for public passenger transport; } \\
\text { - The permanent preoccupation for the } \\
\text { improvement of the relations with the } \\
\text { traveling public by the operative resolution } \\
\text { of their requests and suggestions; } \\
\text { - Good collaboration with the town halls of } \\
\text { the localities from the Petroşani Basin. } \\
\text { - Experience of transport operators in the field } \\
\text { of activity; } \\
\text { - Safety in providing passengers with the } \\
\text { necessary number of means of transport, on } \\
\text { scheduled lines and times; } \\
\text { The current public passenger transport takes } \\
\text { place on } 7 \text { routes, which meet the mobility } \\
\text { requirements of the local population; } \\
\text { Facilities offered to disadvantaged social } \\
\text { groups }\end{array}$ & $\begin{array}{l}\text { - Impossibility to establish alternative routes } \\
\text { due to the geographical configuration of the } \\
\text { Petroşani Basin; } \\
\text { - Improper arrangement of stations; } \\
\text { - Lack of information in stations; } \\
\text { - Decrease in the number of passengers } \\
\text { caused by the increase in the number of } \\
\text { personal vehicles, decrease in population } \\
\text { and reduction in economic activity; } \\
\text { - Lack of a policy of informing and involving } \\
\text { the population in the development and } \\
\text { promotion of sustainable transport } \\
\text { - Increasing pollutant emissions due to road } \\
\text { traffic; } \\
\text { - Low percentage of air-conditioned public } \\
\text { transport }\end{array}$ \\
\hline OPPORTUNITIES & THREATS \\
\hline $\begin{array}{l}\text { - Reducing the level of noise and polluting } \\
\text { emissions by greening and modernizing the } \\
\text { public passenger transport service; } \\
\text { - Placement of explanatory maps with the }\end{array}$ & 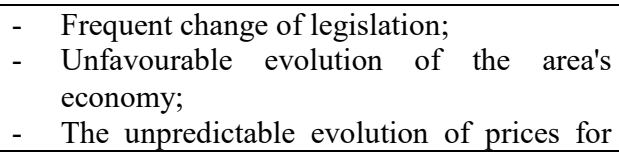 \\
\hline
\end{tabular}


routes and timetable of the vehicles that ensure the public transport of people;

- Implementing a charging system that has high accessibility and attractiveness for users;

- Construction of an intermodal transport terminal in which to transfer between intercounty and local transport in conditions of safety and comfort for passengers;

- Capitalizing on the tourist potential of the Petroșani Basin;

- Carrying out an activity to promote the advantages of traveling by public transport

- Changing the mindset of the population regarding the widespread use of public transport to the detriment of personal vehicles fuels and other materials specific to the transport activity;

Potential competition of the Taxi transport system;

- Reducing the number of passengers if public passenger transport does not become attractive and does not provide optimal travel conditions;

High costs for the purchase of electric buses

In conclusion, the economic and demographic evolution of the Petroșani Basin and the environmental conditions imposed by the need to achieve sustainable transport lead to the need to reorganize the public passenger transport system. In these circumstances, the redesign of the public transport system is of particular importance.

\section{4 "Green Line Jiu Valley" project}

The transport sector is recognized as one of the largest contributors to increasing environmental pollution. To achieve climate neutrality and ensure that sectors with emissions that are more difficult to abate have access to sufficient quantities of renewable and low carbon fuels, conventional cars will need to gradually be displaced by zero emissions vehicles and greater use should be made of sustainable collective transport services. The Impact Assessment projects reduction levels in 2030 corresponding to a decrease of around $50 \%$ of the $\mathrm{CO}_{2}$ emissions per kilometre for passengers' cars, as compared to the 2021 targets. The production and sales of electric vehicles are already taking off, and hydrogen promises new ways of propulsion, particularly for heavy duty trucks, indicating that this is a realistic scenario [14].

The use of a fleet of eco-friendly buses for public passenger transport in urban areas has a whole range of advantages: reducing greenhouse gas emissions, air pollution, and noise pollution, all with public health implications. Implementing a public transport system with electric buses promises important benefits for the environment and economy, as well as the shift towards sustainable mobility in the urban environment.

The project "Green line of electric buses between Petrila-Petroşani-Aninoasa-VulcanLupeni-Uricani - Green Line" develops in the context that in the Petroșani Basin area there is no integrated public passenger transport system that addresses the needs of the population in terms of both mobility, economic efficiency, comfort and pollution reduction [15]. The project aims at investments aimed at improving urban public transport, investments for electric and non-motorised transport, as well as investments aimed at reducing $\mathrm{CO}_{2}$ emissions. The project addresses themes described in existing studies and strategies related to the development of urban mobility by:

- decrease in the frequency of use of personal cars;

- measures to reduce car traffic in certain areas congested by transit traffic;

- the use of clean, high-quality and efficient public transport;

- increasing the attractiveness of public and alternative transport in terms of economic and journey times; 
- reduction of $\mathrm{CO}_{2}$ equivalent emissions;

- construction/modernization of urban public transport stations;

- construction of auto-base and recharging stations for clean public transport.

\section{Conclusions}

The transport of persons is one of the important components of the transport service and transport costs have a sufficiently large share in the general costs, which justifies the orientation of the research in order to reduce them. Reducing negative environmental effects, such as polluting emissions or replacing the fleet with a greener one, is subject to EU requirements.

The paper presents the research carried out in the Petroşani Basin on the activity of public transport of persons in the context of sustainable transport. The urban mobility study carried out concluded that the current public transport system satisfies the capacity and frequency of transport demand, but not in terms of the technical condition of the fleet, spatial accessibility, passenger comfort and safety (inadequate stations, lack of air conditioning in the means of transport, lack of a modern charging system, lack of media in stations etc.).

The shift to the use of a fleet of green buses for public passenger transport in urban areas leads to a number of advantages: reducing greenhouse gas emissions, air pollution, and noise pollution, all with public health implications. The implementation of a public transport system with electric buses promises important benefits for the environment and economy, as well as the shift towards sustainable mobility in the urban environment. The launch of electric buses is one of the measures to achieve the sustainable development goals [1,15].

It is important to stress that time is needed to ensure the implementation of the concept of sustainable development. It is very important to intensify the efforts of all stakeholders local government, population, businesses and organizations of any form of ownership and organizational subordination (including non-governmental, non-profit, public), trade unions, associations and much more. Active cooperation of all stakeholders to adapt and implement the principles of sustainable development in life is one of the prerequisites for todays and future growth.

\section{References}

1. J. Oleśków-Szłapka, I. Pawłyszyn, J. Przybylska, Sustainability, 12 (16), 6510, (2020)

2. http://docs.wbcsd.org/2009/03/MobilityForDevelopment Summary.pdf, [Accessed 12.07.2021]

3. S. Ilie, G. Mitran, I. Tabacu, N. Ilie, V. Nicolae, A. Boroiu, MODTECH 2011, Project management in regional public transport, (Vadul lui Voda, Moldova, 2011)

4. A. Boroiu, G. Mitran, Ingineria Automobilului, 51, 3-3, (2019)

5. https://www.cjhunedoara.ro/documente/anunturi/Linie\%20verde/hotarare,\%20raport,\%20expune re\%20aprobare\%20PMUD.pdf, [Accessed 12.07.2021]

6. A.A. Boroiu, E. Neagu, A. Boroiu, I. Vieru, 8th ACME, Proposals for the reorganization of road traffic in the central area of Pitesti municipality based on microsimulation-performed traffic analyses, (Iasi, Romania, 2018)

7. A. Costache, Vulnerabilitatea aşezărilor umane şi riscurile sociale în Depresiunea Petroşani, (Valahia University Press, Târgovişte, 2010)

8. https://hunedoara.insse.ro/produse-si-servicii/statistici-judetene/populatia/, 12.07.2021]

9. http://mfe.gov.ro/wp-content/uploads/2020/07/b02b3d268774f9adb3c9f655c452aa87.pdf, [Accessed 12.07.2021]

10. A.A. Davidoiu, The Role of Jiu Valley Hard Coal Mining on The Region's Sustainable Future (Doctoral Thesis, University of Petroşani, Petroşani, 2017)

11. https://www.google.ro/maps/, [Accessed 12.07.2021] 
12. http://zmk.ro, [Accessed 12.07.2021]

13. https://www.cjhunedoara.ro/documente/transparenta $\% 20$ decizionala/proiect $\% 20$ tarife $\% 20$ transp ort.pdf, [Accessed 12.07.2021]

14. https://eur-lex.europa.eu/legal-content/EN/TXT/?uri=CELEX:52020DC0562,

[Accessed 12.07.2021]

15. http://213.177.6.117/documente/convocatoare/2019/PH\%20SCAN\%204\%20APRILIE\%202019/ $\underline{\mathrm{SF} \% 20-}$

componenta\%201/Anexa\%201\%20SF\%20Green\%20Line_VJ_C1_Rev.\%20\%2002.04.pdf, [Accessed 12.07.2021] 